New Zealand journal of industrial relations, 1990, 15, 99-116

\title{
ARTICLES
}

\section{New tracks, old maps: continuity and change in New Zealand labour relations 1984-1990}

\author{
John Deeks*
}

This paper discusses the general direction of change in New Zealand's labour relations structures and practices since 1984. It analyses the impact of economic deregulation on the agendas and outcomes of collective bargaining and discusses some of the implications for unions and employers of the restructuring of labour relations. It is argued that an adequate understanding of the changes implemented to date must take into account not only legislative, institutional and macroeconomic factors but the activities of labour relations practitioners at both national and enterprise levels. The article highlights the resilience of New Zealand's national award system, challenges the notion that the New Zealand labour market is particularly inflexible, and questions the assumption that successful economic restructuring must be preceded by labour market deregulation.

\section{Introduction}

Change, 1984-1990

The context

The previous labour system was a serious constraint on growth since it was too rigid and centralised, impeding the flexibility needed for a dynamic economy, reproducing unacceptably low levels of labour productivity and retarding technological development. This system should be changed .... to increase labour mobility, give enterprises greater power over the disposition of labour and weaken the job tenure of state workers (White, 1988).

Although this extract is from an article on labour reform in the People's Republic of China, it could very easily have been part of a speech in the New Zealand Parliament during the passage of the 1987 Labour Relations Act or the 1988 State Sector Act. Since 1984 there has been a radical restructuring of the New Zealand economy incorporating, inter alia, the removal of price and interest rate controls, the discontinuance of import licensing and of state trading monopoly rights, the elimination of exchange controls, the phasing out of export incentives and producer subsidies, the sale of state assets, and the

* Department of Management Studies and Labour Relations, University of Auckland. An earlier version of this paper was presented in June 1989 as part of the University's Winter Lecture Series, 'Change in New Zealand : how are we managing?' 
deregulation of the transport and banking industries. Consequently, New Zealand companies, facing an increasingly unprotected trading environment, have looked much more critically at their labour costs, at their labour management practices and at the institutional constraints incorporated in the country's system of labour relations. Nationally, the debate on labour relations and labour market reform has been dominated by the agendas of the 'new right' or the 'new radicalism'. In the guise of 'Rogernomics', New Zealand's brand of Thatcherite monetarism, a forceful case has been made for a general deregulation of the New Zealand labour market as a necessary element in the development of a more competitive economy. In particular, the institutional arrangements of the labour relations system have been seen as providing barriers to effective economic recovery.

There were a number of major criticisms of the system of labour relations as it had evolved by 1984 , a system that had retained key elements established ninety years earlier by the Industrial Conciliation and Arbitration Act of 1894 :

There was too much government intervention in the wage-fixing process and in the process of dispute settlement.

In 1984 the new Government inherited a wage freeze from the National Party administration, a wage freeze that had been in place since 1982. In the ten years prior to 1982, only the eight months from December 1972 to August 1973, the early months of the third Labour Government, could be legitimately described as a period of free wage bargaining (Boston, 1984). Government intervention in major disputes was the norm rather than the exception. Even when employers and unions were in agreement on a wage settlement they could not be certain that the Government would not pass regulations to override that agreement, the classic example being the Remuneration (New Zealand Forest Products) Regulations 1980 (Deeks and Boxall, 1989, p.201).

The multiple-tier bargaining structure was inflationary in its impact.

National general wage orders and, in the public sector, automatic annual general adjustments to pay rates, could be supplemented by national awards and determinations for particular industries or occupational groups and then further supplemented by bargaining at enterprise level for 'in-house' or company agreements.

There was too great a focus on pay relativity issues.

Issues of 'fair relativity' between one occupational group and another, and broad considerations of pay equity, took precedence over the need for pay scales to reflect changes in labour supply and demand and to provide the necessary signals for labour market adjustment. The institutionalisation of these pay relativities - the direct linkages, for example, between the pay of a carpenter and that of a clerical worker, or of a firefighter with an indentured fitter - created highly rigid pay systems that took little account of technological change and the consequent changes in the skill requirements of different jobs. The system was locked in to historical relativities that no longer had any logic in equity or in economics.

Wage fixing was over centralised.

In the private sector one or two key bargains in the early stages of a wage round would become the trend-setter awards for that year. It was often claimed that 80 to 90 percent of all awards subsequently settled to largely mirror the wage movements of the trend-setters. This centralisation allowed little scope for wage increases to reflect the ability to pay of a particular industry or enterprise and no stimulus to increased 
productivity or improved performance. In the public sector the system of occupational determinations similarly standardised pay and conditions nationally for public servants. In addition, the central negotiation by union and employer officials of pay and conditions in both public and private sectors made the wage fixing system extremely remote form the concerns of employers and union members at the workplace; for many it was hard to see any direct relationship between the work performed and the basic payment received.

\section{There were too many small and inefficient unions.}

The protections and advantages that unions gained by registration under the Industrial Conciliation and Arbitration Act of 1894 , and subsequent legislation, stimulated the creation and survival of a multiplicity of small unions. 67 percent of unions in $1983 \mathrm{had}$ less than 1000 members.

\section{The arbitration system could not cope.}

The backlog of matters for the Arbitration Court's attention was considerable. It was not uncommon for it to take twelve months from the date of filing to the date of hearing.

\section{What changes have taken place?}

The fourth Labour Government made a number of changes that affected both the institutional structures and the practices of New Zealand labour relations. The changed structures were primarily those brought about by the State Owned Enterprises Act 1986, the Labour Relations Act 1987 and the State Sector Act 1988.

It is important to recognise that change in the Government's own behaviour in the labour relations arena, independently of the legislative provisions, has shifted the focus of labour relations. This is most apparent in the commitment of the Government to free wage bargaining, the consequent absence of direct wage controls since the 1984 election, and the Government's predominantly non-interventionist stance in disputes between unions and employers. There is no doubt that employers and unions now have changed expectations about the role of government in wage fixing and dispute settlement and have been weaned away from the idea that government will bail them out if they make a mess of their negotiations or reach an impasse. The early introduction of voluntary arbitration, through the Industrial Relations Amendment Act 1984, gave a clear signal to employer and union parties that they should seek to resolve disputes with a minimum of third party intervention.

Historically, New Zealand's labour relations system has been a highly legalistic one. It is no surprise, therefore, that the changes in the legislative framework since 1984 have provided the primary focus for discussion of labour relations change generally. The general thrust of this legislative reform has been towards increased decentralisation of wage fixing and the encouragement of industry and enterprise bargaining, a push towards the negotiation of agreements that are related to the productivity, profitability and economic realities of individual industries and enterprises. Thus, under the State Owned Enterprises Act 1986, the new state trading corporations were freed of the constraints of the State Services Act 1962 regarding the personnel procedures to be adopted in the appointment, promotion, transfer, discipline, occupational classification and grading of public servants. The Labour Relations Act 1987 sought to eliminate secondary or twotier bargaining by requiring each group of workers' wages and conditions to be determined by a single set of negotiations, a provision thought likely to push workers who had enjoyed rates above those set by national awards into the negotiation of stand alone or composite agreements negotiated at the level of the industry or enterprise. The 
negotiation of composite agreements, that is agreements covering different groups of workers on a single worksite, was also encouraged by the provision whereby those bound by such a document could, on its expiry, return automatically to national award coverage.

The State Sector Act 1988 made each government department, presided over by a chief executive rather than a permanent head, an employer in its own right so that department-by-department agreements began to replace occupationally - based bargaining. In addition the Act gave departmental chief executive officers the authority to hire, promote, discipline, and fire, as the CEO saw fit, providing that the personnel policy complied with the principle of being a 'good employer'.

The push for state-owned enterprises to be market driven and for the core public service to adopt a more managerial mode of operation reflected a belief that private sector systems of organisation and management were economically more 'efficient' than the system that had evolved in the public sector. The State Owned Enterprises Act and the State Sector Act brought about a substantial integration of public sector and private sector management practices. They also substantially integrated the labour relations procedures of the state sector with those of the private sector. The registration of state sector unions, the conduct of their affairs, their membership provisions, and changes in union coverage are all now matters determined under the procedures of the Labour Relations Act. Similarly the disputes and personal grievance procedures of the Act now apply to state sector employees. As in the private sector, arbitration of disputes is only possible if both parties agree to it, although the police and armed forces are exempt from this provision. The other distinction between the arbitration provisions of the public and private sector is in the opportunity for those covered by the State Sector Act to enter into an agreement to be bound by final-offer arbitration. (None of the major public sector unions have entered into such an agreement, however, preferring the freedom to take direct action should voluntary arbitration fail.)

In an attempt to provide a further stimulus for reform in the direction of industry and enterprise bargaining, the Labour Government, late in its second three-year term, introduced the Labour Relations Amendment Bill 1990. Among other things, the Bill proposed an employer right to initiate procedures for the negotiation of an enterprise agreement and the consequent removal from award coverage of the workers who opted for such an agreement. This right was restricted to those employers with a minimum of fifty employees bound by an award or an agreement in any one workplace. In addition the procedure for entering into negotiation of such an enterprise agreement required a secret ballot of the workers concerned, conducted by the Registrar of Unions, to ensure that the majority of those voting were in favour of the employer's proposal for a separate agreement. Such proposals, however, did not go far enough for the National Party. They argued for a policy goal of increasing the flexibility of bargaining arrangements by allowing employers and employees in firms of any size to jointly choose workplace, enterprise or industry bargaining arrangements, and allowing employees to choose the bargaining agent they wished to represent them in collective negotiations.

Although there have, therefore, been a number of key changes in recent labour relations legislation, it is important to recognise that the 1984-1990 period has sustained a number of continuities with the past. The rights guaranteed to registered trade unions under the Labour Relations Act 1987 would be largely recognised by William Pember Reeves as those guaranteed by his 1894 Industrial Conciliation and Arbitration Act, that is : exclusive rights of organisation of those workers' covered by a union's membership rule (modified by an administratively complex process of 'contestability' allowing one union to mount a challenge for another union's membership); exclusive bargaining rights and the ability to effectively force employers into negotiations over wages and conditions; access to conciliation procedures for dealing with disputes of interest and to procedures for the resolution of disputes of rights; 'blanket coverage' provisions whereby awards bind not only the negotiating parties but all other employers and workers carrying out the work specified in the award; and a mechanism for the enforcement of minimum award 
rates of pay, the enforcement now being the responsibility of the unions and employers rather than of government inspectors. Even the membership of the Arbitration Commission and the Labour Court established by the 1987 Act broadly parallels that of the Conciliation Boards and Arbitration Court set up in 1894. In considering the changes made since 1984, therefore, it is important to recognise the legacy of the past, both in the structural and institutional aspects of New Zealand's labour relations system and in the attitudes, expectations and conditioning of unions, employers and government.

\section{What has been the impact of the changes made?}

\section{State owned enterprises (SOEs)}

It is in the state owned enterprises that the most dramatic shift has taken place. Here there is a clear fracture with the labour relations traditions and practices of the past. Conditions of employment that existed prior to the setting up of the state owned enterprises were not carried over into the new corporations and had to be negotiated from scratch. The stress in the SOEs was on commercialisation and economic performance. Private sector employers, a number of them members of the New Zealand Business Roundtable, were appointed to the SOE. boards and senior managers recruited from outside the organisations - 80 percent of Telecom's senior management, for example, were recruited from outside Telecom (Mitchell, 1989).

These factors created pressures to develop labour relations structures and policies that were compatible with the competitive environment in which the SOEs were operating. Walsh has identified the increasing use throughout the SOEs of performance-based salary scales and individual employment contracts, a series of arguments about the level of collective bargaining coverage (Walsh estimated the coverage loss as less than 3 percent in the three corporations covered by the Post Office Union, and between 5 and 15 percent for those covered by the Public Service Association), and no significant union resistance to vastly increased management discretion on personnel issues. He pointed out that, notwithstanding the statutory requirement that the corporations implement equal opportunity programmes, these programmes have also been a casualty of the 'consistent and uniform drive by SOE management to restore managerial discretion in all areas' (Walsh, 1988)

Walsh identified some variation in the labour relations strategies of the different SOEs, drawing a contrast between the antagonistic stance towards unions adopted by Forestry Corp and Electricorp and the higher priority given by N.Z. Post and Telecom to the development of good union relations. Moves to decentralise SOE management structures are reflected in new structures of union-management agreements. Electricorp's seven autonomous business units each have a separate agreement with the Public Service Association (PSA). Telecom and the Post Office Union have negotiated a central core agreement with separate appendices for each subsidiary company.

\section{Core state sector}

In the remainder of the state sector, labour relations change has not been so dramatic as that already effected in the state corporations. But it is as yet early days. Annual general adjustments to state pay rates are no more, and the criteria regarding fair relativity between state pay rates and rates for comparable jobs in the private sector have also disappeared. There has been an increase in short-term contract employment and in the use of consultants. Departmental pay agreements have now largely replaced occupational agreements. However this process was already underway prior to the introduction of the State Sector Bill in December 1987, the PSA having proposed and reached agreement on 
a departmentally-based system of bargaining as part of the 1987-88 wage settlement. In addition it is important to recognise that departmental agreements are essentially national agreements covering all the central, regional and local offices of a particular government department (Clark, 1989).

Pay settlements in the 1988-89 wage round, the first since the passage of the State Sector Act, averaged around 4 percent for those on the lowest rates, less for those on higher incomes; this was less than the rate of inflation and less than the overall average of around 4 percent for the private sector. (All such figures are estimates since it has become increasingly difficult, what with clawbacks on conditions, the extension of agreements beyond their original 12-month terms, the operation of informal memoranda on above award rates etc, to provide an accurate analysis of aggregate wage movements within the sectors. The State Services Commission estimated that the 1988-89 wage round added 2 percent to the wage costs of government departments. 1 The 1988-89 metal trades award settled at 4 percent. Peter Carroll, the Manager of Advocacy and Legal Services at the Auckland Employers' Association claims that 300 other agreements were settled at plus or minus 10 percent of this figure, that is between 3.6 percent and 4.4 percent (Carroll, 1989). The negotiation of these increases took place in the context of direct Government pressure requiring departments to fund internally any wage increases agreed upon. This created a climate where increases had to be financed either through cost savings elsewhere in a department, or through redundancies, or through clawbacks of existing conditions of employment.

Although the structure of state sector agreements has shifted, the framework of their negotiation is still highly centralised. Here the State Services Commission has played a key role as the employer party handling all negotiations on wages and conditions in government departments. As Harbridge and Walsh have pointed out, making government departments financially autonomous units raises the possibility of different conditions of employment being negotiated in different departments. Although the State Services Commission has powers to delegate negotiating authority to departmental chief executives it has not generally chosen to do so. It remains to be seen whether this is a provisional and transitional arrangement, dependent on the development of labour relations skills and expertise within the departments themselves, or a more permanent arrangement entrenching the State Services Commission as both policy maker on personnel and labour relations matters in the public service and as bargaining agent for government departments. The influence of the State Services Commission in the first wage round under the new structures was, in the opinion of Harbridge and Walsh, 'pervasive':

Its role in this round has been akin to that of the Employers Federation in the private sector. Thus, the notion of departmental, and more especially managerial autonomy has remained an ideal rather than a reality. In most respects it has been business as usual in terms of the centralised direction of the employer negotiating position. Nonetheless, there has been some variety in departmental settlements, suggesting that the centralised direction of the round is not being used to impose one uniform pattern of settlement. Indeed, it may have been a major factor preventing such a pattern (Harbridge and Walsh, 1989, p.81). 


\section{Private sector}

The least degree of formal (i.e structural and institutional) labour relations change has been in the private sector. Given the extent of deregulation of that sector since 1984, and the continuing pressures for labour market reform, this may seem surprising. I will canvass a number of reasons shortly on why it should be so; first, however, the evidence. Two broad conclusions stand out from analysis of the 1986-87, 1987-88 and 1988-89 wage rounds (Harbridge and McCaw; 1989; Harbridge and Dreaver 1989; Harbridge, 1990; Grills, 1988). The first is that national awards, even though they have contained smaller percentage wage increases than regionally - negotiated rates or composite agreements, have not been dislodged as the key feature of the wage bargaining system. The anticipated growth in composite bargaining, the unions' preferred method for replacing the old secondary bargaining arrangements, simply has not eventuated. In the 1986-87 round a number of 'pass-on' arrangements were negotiated between unions and employers. These were either legally unenforceable memoranda to the awards or were informal agreements to carry on with the old two tier system while setting up working parties to deal with the restructuring of the award. In a number of cases, however, notably the Metal Trades Award, the major restructuring envisaged has not yet taken place (Deeks and Boxall, 1989, pp.227-228). It was not until the 1989-90 wage round that the first national composite industry award, that for the packaging industry and covering eight unions, was achieved (Sweeney, 1989).

The second broad conclusion is that there is greater wage flexibility in the system than critics have allowed. This is reflected in declining real wages and in the range of wage settlements that have been reached within each wage round; in the failure in a number of cases to backdate awards; in the fact that there are variable rates of wage increase across different industries and occupations; in the presence, over a number of wage rounds, of significant wage dispersion; and in the changes negotiated concerning liberalisation of hours of work. On hours of work, for example, 8 percent of documents renegotiated in 1986-87, and 26 percent of those renegotiated in the 1987-88 round, had a change in their hours of work clause. In this respect the analysis of wage round data provides further evidence to support the conclusions of the New Zealand Planning Council's Economic Monitoring Group report on labour market flexibility, published in 1986. The group reviewed a number of objective measures of wage or pay rate flexibility and of contract flexibility and demonstrated that:

The level of adjustment being experienced in the labour market is much greater than is often realised.... In comparison with the OECD, there is little ground for thinking that the New Zealand labour market is unusually inflexible.... We conclude therefore that discussion of the future of labour market policy should proceed with a recognition that the New Zealand labour market is not as inflexible as is often alleged, but that we could probably achieve a more efficient and equitable use of our resources by enhancing the role of bargaining and providing for more freedom to choose different bargaining patterns.

One of the features of the Labour Relations Act 1987, however, is that it did provide the unions and employers with a greater degree of choice of bargaining arrangements. In this respect it was an enabling piece of legislation rather than a prescriptive one. Initially at least both parties, employers and unions, seemed to be willing to explore the new tracks signposted by the Act. In a small number of cases radical changes were implemented, the most publicly visible being the agreement between Nissan Manufacturing Ltd, and the Auckland Branch of the Engineers Union (Deeks and Boxall, 1989, pp.220-223). More recent agreements have included composite agreements at Masport and Fisher and Paykel and a composite award at Elders NZ Forest Products. Negotiations are also underway at Watties for a set of enterprise agreements for its 
subsidiary companies. But overall, commentators are agreed that any general movement in the direction of industry and enterprise bargaining has been slow and reluctant. In the remainder of this article I want to speculate on a number of reasons why this should be so.

\section{Bargaining structures and bargaining behaviours}

There are a variety of possible explanations for the nature of the labour relations changes that have taken place in New Zealand since 1984. In exploring some reasons for the different rate of change between the public and private sector, and in commenting on the relative inertia in the private sector, I wish to offer some explanatory elements that help illuminate the overall picture rather than present a set of competing theoretical view points. I intend, therefore, to go somewhat beyond the dominant tradition of labour relations commentary in New Zealand which is largely a tradition of institutional analysis within a macro-economic framework. I want to complement this traditional focus by looking at explanations of change that are consistent with the operational realities of labour relations practice at the organisational and enterprise level, that is explanations that take account of the contingency of events and are congruent with the experience, goals, values and deliberate individual choices of labour relations practitioners and decision-makers. I am seeking to interpret and explain change from within the logic of a behavioural (or social action) framework, while remaining sensitive to the constraints of legal, political and institutional structures. This seems to me to be a particularly apposite approach if we wish to understand the extent to which practitioners are prepared to accept or reject the opportunities for change provided by enabling legislation. It also allows some exploration of the kinds of accommodation that are necessary between interest groups if change is to be introduced into organisations without major conflicts and disputes, and those organisations are to adapt effectively to the realities of their changed economic, political or legal environments.

\section{Public and private sector rates of change}

At the macro level Walsh (1989) has argued that the different rate of change between public and private sectors can be explained in part by analysis of the different institutional and political pressures for reform. He sees the less radical nature of the restructuring incorporated in the 1987 Labour Relations Act as stemming from the close personal and political relationships that existed between Government officials, politicians and trade unionists. Such close linkages, however, were absent in the case of the state sector legislation. Thus the state sector legislation was much more directive in the changes to be made, was introduced with far less consultation and was, consequently, less influenced by accommodations between the parties during the passage of the legislation.

Clearly if the public sector is being pushed towards a private sector model of operation then it is natural to expect the movement in public sector practice to be greater - there is simply further for state sector change to go. Nevertheless some of the SOEs have taken more radical steps in the direction of decentralisation of their labour relations structures and practices than is the case with many of the industries in the private sector. Of course the SOEs, large as they are, have an advantage in being single employer organisations. In contrast, changes in industry bargaining in the private sector may require agreement from a multiplicity of employers of different sizes facing different competitive pressures. There has also been a clear wish among the management of the SOEs to develop a new 'culture' in their organisations, a culture that reflects the perceived values of commercial business rather than the values of a public service bureaucracy. It 
is natural that the new managers in the SOEs would desire to mark the change from the old regimes (for example, from the New Zealand Electricity Department to Electricorp) by more than trendy name changes, new corporate logos and a profusion of television advertising. Consequently a symbolic focus of these new regimes has been the creation of a reconstructed labour relations environment in which managerial prerogatives are asserted in an aggressive manner.

In an organisation deliberately pursuing a new culture it is likely to be the chief executive officer who articulates the values to be reflected in changed practices. Walsh, for example, in describing what he calls 'the struggle for power and control in the new corporations' identifies the 'increasingly important role in industrial relations played by chief executives and the loss of predominance by the more pragmatic labour relations professionals' (Walsh, 1988, p.183). This is an issue to which I will return.

\section{The resilience and flexibility of the national award system}

At the micro level in the private sector the picture is much more diverse. There are companies that would like to enter into negotiations for enterprise based agreements but have been constrained by the unwillingness of unions to cite them out of award coverage or by the inappropriateness of the current union structures of organisation and membership to the needs of a decentralised system of collective bargaining. But equally there are companies that are constrained by other employers in their industry from developing an effective form of enterprise bargaining.

There are many employers, particularly in smaller firms, that favour the continuation of national awards, either of an industry or occupational kind. National awards deliver a wage structure at minimal cost to the individual employer; in terms of transaction costs they may be much more efficient than company-based agreements and individual contract negotiations. In other countries it is not uncommon for small employers to pay the going 'union rate' of pay for a job even though they may not be members of their Employers Association or their employees be members of the relevant union - the classic free ride for both parties. In addition, many small employers do not wish to deal directly with union officials or employee representatives on matters of salaries and wages. In a speech to the Auckland Rotary Club in 1987, Derek Sutcliffe of the Auckland Employers Association commented on the marked reluctance of many employers 'to face the reality of the need to meet and negotiate with their own employees. In my experience,' he said 'most managers, no matter how good they are in their specific area of expertise, are nevertheless very reluctant to meet and negotiate with union officials or employee representatives. We should not believe that it is only the unions who are resistant to change (quoted in National Business Review, 30 October 1987).

There is some irony in the fact that it is has been New Zealand's national employer organisations, notably the Business Roundtable and the Employers Federation, that have a decentralised bargaining framework as a major focus of their labour relations and labour market policy, and that it is the unions that are advocating industry-wide agreements and are seen to be clinging to the national award structures. It was not always so. Historically in New Zealand, unions were organised on a regional and district basis and negotiated regional or district awards. It was employers who wished to see regional differentials eliminated and a national award structure created and preserved, both to prevent individual employers gaining competitive advantage by the payment of low wages and to prevent unions using regional variations to continually jack up wages and conditions. The formation of New Zealand-wide unions of employers' was a step taken in order that claims could be filed for national awards and unions prevented from filing for regional documents (Department of Labour, 1985). Judging by past and present union behaviour there is no matter of principle at issue in the question of the preservation of national awards. If there is, it escapes me what it can be. It escapes a lot of unionists 
too. The test of the viability of the national award system would seem to be, from the union point of view, a purely pragmatic test - what does the system deliver and to whom?

There is nothing magical about what the award system has delivered to union members in recent years. It has not been able to sustain the real wages of workers, nor to protect them from clawbacks on conditions, nor to provide them with employment security. It is of course arguable that without the active defence of the award system workers would have been even worse off in terms of wages, conditions and job security. There is a general view among labour relations specialists that in times of recession workers are best served by strong central organisations, national awards or agreements and the centralisation of collective bargaining, and that in times of economic expansion, when labour market conditions are more favourable to workers, decentralised enterprise bargaining is likely to produce the maximum benefits. Those in New Zealand, however, who have made a fetish of national awards in the last few years nevertheless have to confront the reality of what has been achieved in some of the enterprise level agreements. In the case of Nissan, for example, both the major union concerned, the Engineers Union, and the company, were more than satisfied with the outcome of the first year under the agreement. They agreed, and the union had access to the information needed to verify such matters, that there had been improvements in productivity, product quality and in safety, that there were lower rates of staff turnover and absenteeism, and that manufacturing costs had been reduced without reductions in real earnings. Indeed individual wage increases during the first year of the agreement averaged 3.4 percent over and above the base rate and in 1989 base rates were increased by a further 4.5 percent (Denny, 1989). The company increased its market share and an additional 60 shop floor jobs were created in the 15 months to May 1989 (Owen, 1989). Not surprisingly the company and the Engineers Union renewed the agreement for a further 12 months.

There is a tendency in New Zealand to lose sight of how low many national award rates of pay are. It is quite characteristic for a number of award rates at the start of a particular wage round to be below the statutory minimum wage that comes into effect during that wage round. Thus at the start of the 1988-89 wage round, for example, there were 38 awards that had adult rates of pay of less than \$NZ240 per week, (\$NZ235 per week, or \$NZ12,220 per annum, became the statutory minimum wage on 15 May 1989). And the number of workers covered by second-tier agreements has never been very large. If the meat industry is excluded - it is an industry with a long tradition of 'shed' agreements - then less than 10 percent of the remaining workforce would be the beneficiaries of second-tier bargains (Harbridge, 1988). For many workers, then, movements in the national award are their only source of wage increases. And for those on above award rates it will generally be the movement in the award rate that triggers their wage increases too.

\section{Labour market flexibility and deregulation}

Continuing complaints that the minimum wage legislation and the setting of minimum wage rates in national awards are preventing the unemployed from being 'priced back into jobs', and that award conditions create a highly inflexible labour market, are not sustained by a careful analysis of New Zealand's current labour relations and labour market realities. ${ }^{2}$ I have already indicated the reasons for concluding that the New Zealand labour market is not as inflexible as the protagonists for labour market

2 For a detailed analysis of the relationship between pay and employment in New Zealand see Brosnan, P. and Wilkinson, F. (1989) Low pay and the minimum wage. Research Monograph No. 2. Wellington, New Zealand Institute of Industrial Relations Research; low pay, poverty and unemployment have increased significantly in New Zealand since 1984. 
deregulation would have us believe. The evidence from the Economic Monitoring Group Report and from the empirical analysis of the restructuring of wage bargaining suggests that there is a considerable degree of flexibility in practice. Certainly it is possible to point to specific structural rigidities that are entrenched by the system, as for example in the blanket coverage provisions of awards and in the fact that, until the advent of the Labour Relations Amendment Act 1990, it has been in the hands of the unions to choose whether or not a particular employer is cited out of the award to take part in separate negotiations leading to an industry or enterprise agreement. However, I do not believe we should over-emphasise the imperatives of structure. To do so would be to neglect consideration of the individual and collective actions of labour relations practitioners addressing the realities of a competitive deregulated business environment.

What after all is the demand for labour market flexibility about? There are essentially 3 primary and inter-related aspects in which employers in New Zealand have been seeking greater freedom of action under the flexibility rubric - flexibility in pay, flexibility in job demarcations and numerical or contractual flexibility. In all three of these areas there have been substantive changes in New Zealand in recent years. I have already summarised the available research on pay flexibility. On developments in the area of multiskilling and the removal of job demarcations the evidence has not been systematically collated. Here it is necessary to rely at present on anecdotal evidence and on case studies, a fact that reflects a general paucity in New Zealand of comprehensive research on enterprise labour relations practices. In the Nissan agreement, occupational classifications in the manufacturing area were reduced from over 20 to 2 , and a number of other car assembly plants have moved in the same direction with less fanfare. The Engineers Union also has an agreement with Alcan in which the classifications of production workers were reduced from 27 to 2 . Telecom has successfully negotiated the reduction of occupational groups from 40 to 9 . As to numerical or contractual flexibility the evidence of that in the last few years is all too apparent in the large scale redundancies that have occurred in many industries, in the dramatic effects of what is euphemistically called "downsizing", and in the growth in part-time employment, the employment of staff on short-term contracts, and in the use of subcontract labour.

The remaining 'rigidities' complained of include those institutional and procedural constraints that restrain employers from firing people without notice or compensation; the structures for processing personal grievances concerning unfair dismissal, harassment or discrimination; and the statutory provisions regarding equal employment opportunity and pay equity contained in the Employment Equity Act 1990. Indeed any form of equity arrangement in employment contracts may be viewed as a 'rigidity' that interferes with the competitive market. The ultimate logic of complete labour market flexibility is absolute freedom of action for management, and a total loss of individual rights and collective protections for employees.

The New Zealand data, therefore, means that it is appropriate to seriously question the assumption that for economic restructuring to be successful, the deregulation of the labour market must precede the deregulation of industry generally. Rather it would appear that, notwithstanding some institutional rigidities in the labour market, the pressures of deregulation in other areas have been sufficiently strong to force a number of pragmatic adjustments and accommodations in labour relations practices and outcomes. Haworth has pointed out that international research on this issue presents a contradictory picture, but that in the larger OECD economies the evidence suggests 'that traditional bargaining structures may be more resilient than many of the industrial relations 'New Age' thinkers might expect' (Haworth, 1989).

In an environment of free collective bargaining, negotiations are forced to take into account the parameters of the changed economic environment of industries and enterprises and the shifts in demand for labour that are consequent upon changing demands for products and services. One of the reasons that private sector employers in New Zealand have not pushed more rigourously for the dismantling of national awards is precisely 
have not pushed more rigourously for the dismantling of national awards is precisely because they have obtained in considerable measure the kinds of flexibility that they have sought without radical restructuring of these documents. And where they have not obtained the flexibility desired they have increasingly been prepared, in a period when arbitration of interest disputes has not been compulsory, to force the reorganisation of bargaining by allowing an award to lapse and then toughing it out against any industrial action that a union might choose to take, the most notable examples being in the general clerical award and the tearoom and restaurant award. (Under the provisions of the Labour Relations Amendment Act 1990, such disputes may in future be dealt with through a process culminating in final offer arbitration.)

Having said that, however, let me also make a number of qualifications. First, New Zealand's economic environment since 1984 has not been conducive to radical reform of the wage bargaining structure. Much time and energy has gone into the negotiation of redundancy agreements and into personal grievance issues (particularly over dismissal questions). Plant closures and rising unemployment have meant that for many unions and companies survival has been the bottom line. The changing of bargaining structures takes time and takes some measure of confidence between the parties that there are mutual benefits to be gained from the process.

Second, the restructuring of unions has not yet moved in directions that facilitate new bargaining arrangements at the industry or enterprise level. The Labour Relations Act 1987 required registered unions to have a minimum of 1000 members. The Act provided two years grace during which the large number of unions with less than 1000 members could seek amalgamation to meet this new membership provision. As the table below indicates, a substantial proportion of union amalgamations came into effect between April and September 1989. They are, therefore, too recent in origin to have substantively changed the patterns of coverage of collective agreements and awards.

Table 1: Number and size of New Zealand unions, December 1986 to September 1989

1989

December 1986 April 1988 April $1989 \quad$ September

\begin{tabular}{lllll}
\multicolumn{2}{c}{ Unions } & Unions & Unions & Unions \\
Size & No Percent & No Percent & No Percent No Percent
\end{tabular}

less than 1000

members

147

65.9

135

58.2

69

41.1

19

17.0

1000 members

and over

76

34.1

97

41.8

99

58.9

9

83.0

Total

100.0

$232 \quad 100.0 \quad 168$

$100.0 \quad 112$

100.0

Notes: 1. * Excludes 31 state service organisations brought under the Labour Relations Act on 1 April 1988.

2. Source: Fuller (1989), p.3

Some of this reorganisation of unions has taken place along industry lines, as, for example, in the grouping of the storeworkers, drivers and shop workers' unions into the distribution workers federation; in the opinion of the Registrar of Unions a third of the 
amalgamations 'were not inconsistent in general with an "industry" type approach at national or semi-national level' (Fuller, 1989).

In other cases, however, amalgamations of unions have taken place on the basis of personal alliances between union secretaries, on the basis of the traditional portfolios of unions covered by particular secretaries, or on the basis of national consolidation of existing craft or occupational unions.

Third, the situation for many employers has not been favourable to planned change in labour relations structures. Mergers, amalgamations and changes of ownership have led to a considerable devotion of management energy to the restructuring of corporate hierarchies and systems, to say nothing of the uncertainties, insecurities and redundancies faced by managers themselves in the last few years. In such an environment it is not surprising that, even though labour relations practices may be changing, longer-term formal changes in labour relations structures are given low priority.

\section{Management ideologies and the labour relations practitioner}

Let me now further develop the argument that understanding the micro-organisational worlds of managements and unions is necessary to an adequate explanation of the changes in labour relations that have (and have not) taken place in the 1984-1990 period in New Zealand. To do so it is necessary to introduce briefly the distinction, well established in the labour relations literature, between unitary and pluralist management ideologies.

The unitary ideology asserts the legitimacy and supremacy of management rights in the organisation and emphasises the need for all the members of the organisation to support management in achieving its goals and objectives. It emphasises 'management's right to manage' and 'managerial prerogative', and utilises images of the organisation as a family or a team to encourage co-operation and commitment from employees. It is the dominant philosophy in Japanese companies where it provides an effective fusion between the single-minded rationality of scientific management and the character traits and social customs of an ancient culture that emphasises hierarchy and the obligations people have to groups to which they belong - family, company, country, and race (Hacker, 1989).

The pluralist ideology, in contrast, views the organisation as a coalition of interest groups, or stakeholders, each with its own agenda. These groups will serve common organisational purposes only because doing so is the necessary route to the satisfaction of the objectives of the group. Their organisational commitment is instrumentally oriented. A management with a pluralist ideology is one that accepts the legitimacy of such groups and seeks to establish effective working relationships with them by bargaining and negotiation and by some element of power-sharing (Deeks and Boxall, 1989, pp.256-259).

In New Zealand most labour relations practitioners have learned, no matter what their personal beliefs, to operate within a pluralist framework. Thus, finding common ground, making compromises, doing deals, accepting the need to build relationships of mutual respect, have all been part and parcel of the practice of labour relations both at the enterprise level and in national negotiations between union and employer officials. At the level of the firm this has often meant that labour relations practitioners on the management side have had considerable difficulties dealing with their own more unitaristminded management colleagues, particularly those more senior in the organisational hierarchy. The modus operandi tacitly accepted as the means of resolving this internal management conflict between belief and practice was for top management to keep out of the labour relations arena and for labour relations executives to be kept off the board of directors. Unfortunately, however, this modus operandi, while it kept organisations functioning effectively - it had essentially a system maintenance role - did little to contribute ideas and energies for organisational change. In an environment of increased 


\section{John Deeks}

competition, of rapid technological development, and of greater emphasis on the strategic aspects of investments in human capital, the system maintenance role of the traditional pragmatic, labour relations practitioners has been downgraded in value.

In New Zealand since 1984, labour market, labour relations and personnel issues have been a key focus of ideologists keen to reinforce a unitarist frame of reference in corporate affairs.

This has been particularly apparent in some of New Zealand's state owned enterprises, partly, I suggest, as a reflection of the 'new right' beliefs of key SOE directors and partly as a consequence of the desire to build new management cultures in those organisations. The revival of the cult of the chief executive as boss, as charismatic visionary leader, has led to a general acquiescence in the view that change can only be effectively implemented by direction from the top. By and large, accommodation with interest groups, especially with those groups that are needed to implement the changes required, is seen as weakness. Indeed, there has grown up a rhetoric that suggests that there is something reprehensible about accommodations between interest groups, that such accommodations are against the general public welfare or public interest. One of the historical lessons of labour relations is that organisations cannot effectively operate without such accommodations and that there are mutual benefits to be gained from consultation, co-operation and negotiation over the nature of people's work and the conditions of their employment. There is a need to extend the agendas of information sharing, consultation and negotiation, not curtail them. The same conclusion has emerged in studies of the effective implementation of technological change in organisations. Organisations that have stressed employee participation in decisionmaking on new technology, and used new technology to create strategic competitive advantage for the enterprise, have had more support from their staff for the introduction of new technology than organisations that have preserved management prerogative on strategic decisions and used new technology to deskill labour and strengthen managerial control and supervision at the workplace (Deeks and Boxall, 1989; Deery, 1989). Dennis Rose (1986) has argued in a similar vein in respect to the debate over labour market flexibility. He suggests that it is a faulty conceptualisation to see labour market adjustment and flexibility as, a priori, 'good' and so-called institutional rigidities as a priori, 'bad'. The questions that have to be addressed are, firstly, what such rigidities achieve in terms of the delivery of necessary and economically beneficial trade-offs and accommodations between conflicting interest groups, and, secondly, what they achieve in terms of equity issues.

\section{Educational and organisational implications of restructuring}

Bargaining about new technology, about methods of work organisation, about productivity and product quality, about employee involvement or worker participation in all its guises, can only be effectively conducted at the level of the enterprise. Such enterprise level bargaining, however, goes against the traditional grain of collective bargaining practices in New Zealand. Traditional bargaining has been geared to the centralised negotiation of basic rates of pay and conditions. Unions and employers in such negotiations have characteristically worked at arms length from each other and concentrated on dividing up the available economic pie. As a consequence they have had little opportunity to develop the climate of trust necessary to tackle effectively some of the problems that require joint co-operation rather than competition between them; indeed they have found a certain comfort in the continuation of established stand-off relationships. This centralised and predominantly conflict-based historical tradition in collective bargaining in New Zealand poses particular difficulties for both unions and management at the current time when there is a strong movement towards enterprise bargaining. 
Enterprise bargaining requires both a co-operative negotiation strategy and a decentralised bargaining framework. It requires unions and managements to invest time, energy and resources in detailed analysis of aspects of working practices and the organisation of work that have a bearing on productivity, product quality, and worker development and satisfaction. Such a decentralisation of collective bargaining needs, if it is to be effective, a greater devolution of decision-making in trade unions and employer organisations. It needs strong union organisation at the workplace level and the broadening of the collective bargaining agenda to include a range of non-wage issues related to enterprise management. It needs a corporate willingness to 'open the books' so that employees and their representatives can assess company financial statements and budget projections for themselves in order to assess 'ability to pay' arguments and to examine the costs and benefits of new working practices. And it needs a union willingness to engage fully in understanding the detailed techniques used by management in work measurement, productivity measurement, performance appraisal, job evaluation, quality improvement, systems design, technology assessment - in all those areas where operational and strategic decisions will have a direct bearing on the nature of the work and the security of employment in an organisation.

At the current time many unions and managements in New Zealand do not have the skills or the organisational resources to develop effective industry or enterprise bargaining. On the union side there is a recognised need to increase the emphasis on the education and training of delegates, to provide greater specialist advice from union officials to workplace representatives, and to develop a more informed understanding of strategic management issues and their consequences for union members. If the unions do not address the organisational, educational and resource issues that arise in the context of developments in industry and enterprise bargaining, they are likely to find themselves increasingly marginalised. They have already been badly affected by the process of economic restructuring. Unemployment has had a severe impact on their membership base. The growth of part-time and contract employment has increased the size of the secondary or peripheral labour market, a segment that is difficult to organise. National awards have not been able to protect real wages nor provide security of employment, whereas greater protections have been delivered by composite agreements and by enterprise bargains. And a number of employers, under pressure from their own loss of economic protections, have demanded and obtained major concessions on working practices with minimal union resistance or involvement. It is primarily at the level of the enterprise that the unions need to demonstrate to their members that the protection of those members' interests is compatible with improvements in corporate efficiency, productivity and profitability.

The movement towards restructuring labour relations institutions and practices and towards greater decentralisation also has important implications for management education. Some traditional managerial attitudes towards trade unions and towards the role of trade unions and employers in decision-making within an enterprise need revision. Many of these attitudes are based on fear and ignorance. The fact that many employers are uneasy about dealing with their own staff on matters of wages and conditions and on aspects related to the management and organisation of work in their enterprises, is a sad reflection on the extent to which the centralisation of labour relations matters in New Zealand has led to a low priority being placed on the development of workplace relationships between management and employees, employers and unions.

In the past the extension of collective bargaining agendas at the workplace or enterprise level has been held back by the relatively low organisational status of human resource managers and by attempts to segregate the management of labour relations from other aspects of the organisation's business. This led to a general lack of involvement of human resource specialists in the technological policy decisions made within enterprises and in broader issues of labour market analysis and of manpower planning. Consequently many human resource managers, like many trade unions, found themselves 
dealing with the purely administrative and executive aspects that flowed from economic restructuring and technological change. They had little input at the strategic and policy levels. If they are to have some impact at these levels they need to develop a more sophisticated analysis of the implications of economic and technological change for work and employment in their organisations and a more active role in the introduction and management of new production, information and communications technologies.

\section{Conclusion}

In this article I have attempted to throw some light on the complex interaction between structural factors in a labour relations system and practitioner behaviour in collective bargaining. The perspective is one that embodies a pluralistic multi-causal approach to change. It recognises that where the legislative framework of a labour relations system provides a range of options for the structure of bargaining - a permissive structural agenda - then the practices entered into by the parties will be influenced by a broad range of factors. These factors will include economic developments at macro and micro level, rates of technological change, membership or constituent expectations, current ideological 'fads', and the nature of the financial, organisational and educational resources at the disposal of the parties.

The New Zealand labour relations experience since 1984 has been one in which a previously highly regulated and insulated labour relations system has been exposed indirectly to the 'extension of the market' and to the 'competitive menace' of international monopoly capitalism. ${ }^{3}$ To date the changed economic environment has had diverse impacts, impinging differentially on the public and private sectors and on different industries. Consequently no unidirectional and systematic relationships can be traced between the changed economic environment, the new institutional and legal frameworks within the labour relations system, the structures of collective bargaining and workplace labour relations practices. Some element of economic determinism must clearly be allowed for in interpreting events in New Zealand labour relations since 1984. So too must some element of institutional constraint, although the constraint has not been sufficient to totally hinder local workplace initiatives.

In the immediate future it seems likely that pressures will build for some kind of bifunctional structure of labour relations to develop in New Zealand. In the large companies, the state owned enterprises and in the public sector, the emphasis will increasingly be on the development of industry-wide and enterprise agreements and on managerial strategies and policies that focus on human resource development, functional flexibility and the regulation of the internal labour market of the organisation. In the small companies, where the conditions of competitive capitalism create major incentives for employers to standardise the price of labour, and where the transaction costs of enterprise agreements are too high relative to their perceived benefits, reliance is likely to continue to be placed on nationally negotiated occupationally-based awards to set rates of pay and conditions of employment. Thus New Zealand's long established system of national awards is likely to continue to provide a major pillar of the industrial relations system, albeit with far greater diversity around the periphery.

3 J.R. Commons, in a 1909 article on the history of American shoemakers, argued that the 'extension of the market' and the 'competitive menace' were key environmental factors shaping the development of the American labour relations system; see Gospel, H. and Littler, C. (eds), (1986) Managerial strategies and industrial relations. Aldershot, Gower, chapter 1. 


\section{References}

Boston, J. (1984) Incomes policy in New Zealand. Wellington, Victoria University Press for the Institute of Policy Studies.

Brosnan, P. and Wilkinson, F. (1989) Low pay and the minimum wage. Research Monograph No. 2. Wellington, New Zealand Institute of Industrial Relations Research.

Carroll, P. (1989) Seminar presentation, University of Auckland, 28 April 1989.

Clark, C. (1989) A case study on industrial democracy in the public service. Paper presented to Industrial democracy/employee participation seminar. Industrial Relations Centre, Victoria University of Wellington (May).

Deeks, J. and Boxall, P. (1989) Labour relations in New Zealand. Auckland, Longman Paul.

Deery, S. (1989) Recent developments in productivity bargaining. Paper presented to Initiatives in human resource management conference. Auckland, Longman Professional (April).

Denny, P. (1989) Consultative and co-operation agreements - their usefulness to develop change. Paper presented at Initiatives in human resource management in New Zealand Conference, Auckland, Longman Professional (April).

Department of Labour (1985) Industrial relations: a framework for review. (The Green Paper), Vol.2: 69. Wellington, Department of Labour.

Economic Monitoring Group (1986) Labour market flexibility. Wellington, New Zealand Planning Council.

Fuller, C. (1989) The functioning of the Labour Relations Act 1987 - unions. Presented by the Registrar of Unions to a seminar on the Labour Relations Act 1987. Wellington, Industrial Relations Centre, Victoria University (October).

Gospel, H. and Littler, C. (eds) 1986 Managerial strategies and industrial relations. Aldershot, Gower.

Grills, W. (1988) Labour market flexibility: wage relativities under the Labour Relations Act 1987. New Zealand journal of industrial relations. 13(2): 157-166.

Hacker, A. (1989) Do we have what it takes? Review of Fallows, J. More like us: making America great again. New York, Houghton Mifflin 1988. In The New York review 30 March:6.

Harbridge, R. (1988) Whatever happened to second tier settlements? A survey of settlements under the Labour Relations Act 1987. New Zealand journal of industrial relations. 13(2):143-156.

Harbridge, R. (1990) Emergent trends in wage bargaining in New Zealand: the 1988-89 wage round. (Forthcoming). 


\section{John Deeks}

Harbridge, R. and Dreaver, M. (1989) Changing patterns of working time arrangements in registered collective settlements in New Zealand. New Zealand journal of industrial relations. 14(3): 251-266.

Harbridge, R. and McCaw, S. (1989) The first wage round under the Labour Relations Act 1987: changing relative power. New Zealand journal of industrial relations. 14(2): 149-167.

Harbridge, R. and Walsh, P. (1989) Restructuring industrial relations in New Zealand: 1984-1988. Labour and industry. 2(1): 60-84.

Haworth, N. (1989) Industrial restructuring and industrial relations in New Zealand: towards a new consensus? Paper presented to Economic restructuring and industrial relations conference. Sydney (March).

Mitchell, A. (1989) Radical restructuring of personnel and employee relations policies the Telecom experience. Paper presented to Initiatives in human resource management in New Zealand conference. Auckland, Longman Professional (April).

Owen, B. W. (1989) Nissan New Zealand : a case study of employee participation. Paper presented to Industrial democracy/employee participation seminar. Industrial Relations Centre, Victoria University of Wellington (May).

Rose D (1986) The pursuit of full employment: macro economic perspectives. New Zealand journal of industrial relations. 11(2): 65-75.

Sweeney, M. (1989) Composite bargaining. Paper presented to The revolution in rewards strategy conference. Longman Professional (May).

Walsh, P. (1988) The struggle for power and control in the new corporations: the first year of industrial relations in the state-owned enterprises. New Zealand journal of industrial relations. 13(2): 179-189.

Walsh, P. (1989) A family fight? Industrial relations reform under the fourth Labour Government. In Easton, B. (ed) (1989) The making of Rogernomics. Auckland, University Press.

White, G. (1988) State and market in China's labour reforms. Journal of development studies. 24(4): 180-202. 